\title{
Analisis Proses Perawatan Auxiliary Power Units pada Pesawat Udara (Studi Kasus: Keterlambatan Pengembalian APU GTCP 131-9 di PT GAA Tbk)
}

\author{
Analysis of the Treatment Process of Auxiliary Power Units in Aircraft \\ (Case Study: Delay in Returning APU GTCP 131-9 at PT GAA Tbk)
}

\author{
Nur Fadilah Fatma ${ }^{1}$, Henri Ponda ${ }^{{ }^{*}}$, Bayu Munggara ${ }^{1}$ \\ ${ }^{1}$ Program Studi Teknik Industri, Universitas Muhammadiyah Tangerang, Jalan Perintis Kemerdekaan I No.33, \\ Cikokol, Babakan, Kota Tangerang, Banten, 15118, Indonesia
}

Diterima: 1 Mei, 2019 / Disetujui: 1 Agustus, 2019

\begin{abstract}
PT. GAA is an international company that employs 4300 employees based in Tangerang, Banten, Indonesia. PT. GAA is able to maintain and repair aircraft, ranging from light repair maintenance to overhauls, maintenance and repair of engines, APU (Auxiliary Power Units) and aircraft components, and cabin modifications. The time to complete the repair of APU sometimes exceeds the Turnaround Time (TAT) that is determined which is 45 days. In fact, there are many delays that occur in returning APU to consumers. In this research report applying the Gantt chart, RCA and 5 Whys Analysis methods, to find out the main causes of delays in the repair process through 10 gates and to find out which gate has the longest delay. From the results of the study, it was found that after the 131-9 APU data collection amounted to 30 units, for 1 year, it was found that the gate which experienced the longest delay was Gate 5, Gate 3, Gate 8 and Gate. 7 and the main cause is the limited ability to repair the APU, the lack of personnel ready to work and the technical problems that occur during APU testing and limited assembly space, equipment for APU assembly and supplies.
\end{abstract}

Keywords: APU, Turnaround Time, Delay, Root cause analysis, 5 whys analysis

\begin{abstract}
ABSTRAK
PT. GAA adalah sebuah perusahaan internasional yang mempekerjakan 4300 karyawan yang berbasis di Tangerang, Banten, Indonesia. Perusahaan mampu melakukan perawatan dan perbaikan pesawat udara, mulai dari perawatan ringan hingga overhaul mesin, Auxiliary Power Unit (APU) dan komponen pesawat, serta modifikasi kabin. Waktu penyelesaian perbaikan APU terkadang melebihi Turnaround Time (TAT) yang ditentukan yaitu 45 hari. Pada kenyataannya banyak sekali keterlambatan yang terjadi dalam pengembalian APU kepada konsumen. Penelitian ini menerapkan metode Gantt chart, Root Cause Analysis dan 5 Whys Analysis, untuk mengetahui penyebab utama keterlambatan dalam proses perbaikan melalui 10 gerbang dan untuk mengetahui gerbang mana yang memiliki keterlambatan terpanjang. Setelah mengumpulkan data APU 131-9 berjumlah 30 unit, selama 1 tahun, ditemukan bahwa gerbang yang mengalami keterlambatan terpanjang adalah Gerbang 5, Gerbang 3, Gerbang 8 dan Gerbang. 7. Penyebab utamanya adalah kemampuan terbatas untuk memperbaiki APU, kurangnya personel yang siap bekerja dan masalah teknis yang terjadi selama pengujian APU dan ruang perakitan terbatas, peralatan untuk perakitan dan persediaan APU.
\end{abstract}

Kata Kunci: APU, Turnaround Time, Delay, Root cause analysis, 5 whys analysis

\section{PENDAHULUAN}

\subsection{Latar Belakang}

Kebutuhan transportasi di dunia sudah sangat tinggi, oleh karena itu sarana transportasi semakin meningkat. Dari sekian banyak sarana transportasi, salah satunya yang dibutuhkan oleh setiap instansi terdapat pada dunia penerbangan, semakin tinggi kemampuan teknologi pesawat udara suatu instansi, maka semakin tinggi pula tingkat keberhasilan dari misi penerbangan dan

*email: henri.ponda@gmail.com 
keselamatan penerbangan tersebut.

PT. GAA adalah sebuah perusahaan internasional yang mempekerjakan 4300 karyawan yang berbasis di Tangerang, Banten, Indonesia. Perusahaan ini melayani pesawat udara dari berbagai jenis dan salah satu yang terbesar fasilitas perawatan dan perbaikan di Asia. Perusahaan mampu melakukan perawatan dan perbaikan pesawat udara, mulai dari perawatan ringan hingga overhaul mesin, Auxiliary Power Unit (APU) dan komponen pesawat, serta modifikasi kabin. Agar dapat memberikan pelayanan yang maksimal, perusahaan didukung oleh beberapa unit produksi, diantaranya line maintenance, base maintenance, component maintenance, seat maintenance, dan engine maintenance. Engine maintenance sering juga disebut engine shop yang tugas utamanya merawat mesin dan APU pesawat.

APU adalah sebuah perangkat pada kendaraan yang menyediakan energi untuk fungsi lain selain propulsi. Mereka biasanya ditemukan pada pesawat besar, serta beberapa kendaraan darat besar. Tujuan utama dari APU yang terdapat pada pesawat adalah untuk memberikan kekuatan pada saat memulai mesin utama. Turbin mesin harus dipercepat untuk kecepatan rotasi tinggi untuk memberikan kompresi udara yang cukup untuk membuat mesin dapat beroperasi secara mandiri. Mesin jet yang kecil biasanya dimulai oleh sebuah motor turbin udara. Sebelum mesin di hidupkan, APU dihidupkan, umumnya oleh baterai atau hidraulik akumulator. Pentingnya perawatan unit ini maka diharuskan perencanaan perawatan yang baik tidak hanya itu saja pentingnya waktu perawatan merupakan salah satu poin terhadap konsumen akan hal ini dibutuhkan perencanaan perawatan yang tepat dengan Turnaround Time (TAT).

Secara umum, TAT berarti jumlah waktu yang dibutuhkan untuk memenuhi permintaan pelanggan. Waktu penyelesaian TAT adalah interval waktu sejak saat penyerahan suatu proses sampai proses penyelesaian selesai.

Waktu penyelesaian perbaikan APU terkadang melebihi TAT yang ditentukan yaitu 45 hari. Faktanya, banyak sekali keterlambatan yang terjadi dalam pengembalian APU kepada konsumen. TAT merupakan bagian dari siklus perbaikan yang termasuk dalam manajemen offwing (Rajarajan, 2014). TAT dilakukan dengan perjanjian/kontrak toko dengan persyaratan kepemilikan suku cadang sehingga dapat meningkatkan manajemen siklus perbaikan (International Air Transport Association, 2014). TAT terutama ditinjau untuk menghitung tingkat inventaris yang harus dipegang oleh maskapai untuk mempertahankan operasi dalam menghadapi risiko (International Air Transport Association, 2015). Dengan peranan TAT dalam manajemen biaya perawatan, keterlambatan pengembalian APU yang melebihi TAT standar menyebabkan berbagai masalah, salah satunya yaitu semakin banyak waktu terbuang (time waste), banyaknya kritik dari konsumen, berkurangnya produktivitas. Penambahan jam orang kerja (man hours) ini menyebabkan penambahan biaya karena menggunakan hari kerja yang tidak sesuai dengan jadwal.

\subsection{Identifikasi Masalah}

Berdasarkan latar belakang yang telah diuraikan sebelumnya, dapat dirumuskan beberapa masalah yang menjadi bahasan dalam penelitian ini mengenai proses perbaikan di Unit APU Maintenance, yang tentunya berhubungan dengan TAT.

Penelitian ini membahas masalah TAT pada perbaikan APU GTCP 131-9. Hal ini terkait dengan keterlambatan yang bisa menimbulkan kritik dari pelanggan yang disertai dengan penurunan nilai Customer Satisfaction Index (CSI) dan kurangnya tingkat produktivitas.

\section{METODOLOGI}

Penelitian dimulai dengan studi pendahuluan yang dilakukan baik secara studi lapangan maupun studi pustaka. Studi lapangan dilakukan dengan cara wawancara mendalam (in-depth interview) kepada perusahaan mengenai perawatan komponen yang dilakukan dalam proses perbaikan pada APU 131-9. Auxiliary Power Unit (APU) adalah sebuah perangkat pada kendaraan yang menyediakan energi untuk fungsi lain selain propulsi. Mereka biasanya ditemukan pada pesawat besar, serta beberapa kendaraan darat besar. Selain itu, studi lapangan juga dilakukan dengan tinjauan langsung ke dalam proses disassy dan piece part APU yang akan dilakukan perawatan dengan melakukan kontrol terhadap komponenkomponen APU yang diperbaiki baik secara perbaikan oleh internal maupun oleh eksternal. 


\subsection{Teknik Pengumpulan Data}

Dalam proses pengumpulan data terhadap suatu penelitian yang dilakukan, maka peneliti harus memiliki cara atau teknik untuk mendapatkan data atau informasi yang baik dan terstruktur serta akurat dari setiap apa yang diteliti, sehingga kebenaran informasi dan data yang diperoleh dapat dipertanggungjawabkan.

Adapun teknik pengumpulan data yang dipergunakan oleh peneliti adalah sebagai berikut:

1. Observasi.

Pada proses observasi, terdapat berbagai metode pengambilan data dalam penelitian. Metode observasi merupakan metode paling penting dan harus mendapatkan perhatian selayaknya. Observasi mengungkapkan gambaran secara sistematis mengenai peristiwa, tingkah laku, benda atau karya yang dihasilkan dan peralatan yang digunakan.

2. Wawancara (interview).

Wawancara (interview) atau kuesioner lisan, adalah sebuah dialog yang dilakukan oleh pewawancara untuk memperoleh informasi dari terwawancara atau narasumber (Arikunto, 2006). Dalam metode ini, peneliti melakukan proses tanya jawab terhadap pihak engineer, pemilik engine/APU dan teknisi assy \& disassy tentang objek yang diteliti. Peneliti mengajukan beberapa pertanyaan yang mengacu ke permasalahan yang sedang dihadapi dengan tujuan memperoleh informasi akurat untuk dijadikan sebagai acuan.

\subsection{Analisis dan Pengolahan Data}

Teknik analisis data merupakan suatu langkah yang paling menetukan dari suatu penelitian, karena analisis data berfungsi untuk menyimpulkan hasil penelitian. Teknik analisis yang digunakan adalah:

1. Analisis keterlambatan APU dengan metode 7 Tools dan Gantt chart.

2. Analisis selanjutnya adalah mencari penyebab keterlambatan proses perbaikan APU dengan 5 Why's Analysis. Analisis ini digunakan untuk mencari akar permasalahan dengan menanyakan kepada narasumber di bidang terkait dengan pertanyaan "mengapa" sebanyak 5 kali sampai ditemukan akar permasalahan.

\subsection{Tahapan Penelitian}

Langkah-langkah penelitian merupakan penjabaran singkat yang menggambarkan keseluruhan tahap proses penelitian dari tahap memulai penelitian hingga selesai penelitian, langkah-langkah yang dilakukan dalam melaksanakan penelitian ini adalah:

1. Rumusan masalah dan tujuan penelitian

2. Pengumpulan data untuk mengetahui hasil atas rumusan masalah dan tujuan penelitian yang telah disebutkan sebelumnya, maka diperlukan data-data yang relevan. Data yang dikumpulkan adalah data primer dan data sekunder. Dari kegiatan tersebut maka penulis berhasil mendapatkan data yang dibutuhkan.

3. Pengolahan data. Pada tahap pengolahan data, data dirangkum dan diseleksi berdasarkan pada pokok permasalahan yang telah ditetapkan dan dirumuskan sebelum kegiatan penelitian dilaksanakan. Hal ini sekaligus mencakup proses penyusunan data ke dalam berbagai fokus, kategori atau permasalahan yang sesuai. Salah satu pengolahan data yang dilakukan adalah penjadwalan, dimana penjadwalan adalah kegiatan pengalokasian sumber-sumber atau mesin-mesin yang ada untuk menjalankan sekumpulan tugas dalam jangka waktu tertentu (Baker, 1974). Penjadwalan produksi adalah suatu kegiatan memasukkan sejumlah produk yang telah direncanakan ke dalam proses pengerjaannya (Biegel, 1992). Penjadwalan adalah proses pengurutan pembuatan produk secara menyeluruh pada beberapa mesin (Conway, Maxwell dan Miller, 2003). Salah satu metode penjadwalan pekerjaan untuk proyek khusus adalah dengan menggunakan diagram Gantt. Gantt chart adalah contoh teknik nonmatematis yang banyak digunakan dan sangat popular di kalangan para manajer karena sederhana dan mudah dibaca (Madura, 2007). Pada akhir tahap ini, semua data yang relevan diharapkan sudah tersusun dan terstruktur sesuai kebutuhan.

4. Teknik analisis data dilakukan dalam satu proses. Proses pelaksanaannya sudah harus dimulai sejak awal penelitian dimulai hingga akhir penelitian. Salah satunya adalah dengan menggunakan metode RCA yaitu teknik analisis yang bertahap dan terfokus pada penemuan akar penyebab suatu masalah, dan bukan hanya melihat gejala-gejala dari suatu 
masalah. Metode root cause analysis ini dikembangkan oleh pendiri Toyota Motor Corporation yaitu Sakichi Toyoda yang menginginkan setiap individu dalam organisasi mulai level top management sampai shopfloor memiliki skill problem solving dan mampu menjadi problem solver di area masing-masing. Oleh karena itu, semua data dan informasi yang didapat pada suatu penelitian harus segera dituangkan ke dalam tulisan dan dianalisis menggunakan metode 5 why dan metode diagram sebab akibat. Analisis data adalah proses mencari dan menyusun secara sistematis data yang diperoleh dari hasil wawancara, catatan lapangan dan dokumentasi, dengan cara mengorganisasikan data ke dalam kategori, menjabarkan ke dalam unit-unit, melakukan sintesis, menyusun kedalam pola, memilih mana yang penting dan mana yang akan dipelajari, dan membuat kesimpulan sehingga mudah dipahami diri sendiri maupun orang lain (Sugiyono, 2011).

5. Penyajian data.

Setelah proses data, selanjutnya data diolah atau dianalisis kembali dengan menyusun atau menyajikan ke dalam uraian, tabel, gambar, dan dideskripsikan secara sistematis, Dalam tahap ini sudah dapat dilihat hasil dari penelitian dan jawaban atau rumusan masalah serta tujuan penelitian.

6. Penyajian kesimpulan.

Pada tahap ini, data dapat dipahami secara langsung oleh peneliti untuk kemudian diambil poin-poin penting dan dijadikan kesimpulan, sehingga hasil penelitian dapat dengan mudah dipahami oleh pembaca.

Pengumpulan dan Pengolahan Data

1. Histori perawatan APU pada tahun 2017

2. TAT tertunda

3. Check sheet total TAT

4. Pareto TAT

Analisis Data

Metode 5 Why's

Simpulan dan Rekomendasi

Gambar 1. Alur Proses Penelitian

\section{HASIL DAN PEMBAHASAN \\ 3.1 Pengumpulan Data}

Dalam tahapan ini merupakan proses awal dari pelaksanaan penelitian sebelum melanjutkan ke dalam proses analisis. Proses ini adalah proses pengumpulan data, semua data yang dibutuhkan dalam proses penelitian yang diambil dan dikumpulkan selama proses penelitian berlangsung. Adapun data primer diambil dari hasil pengecekan dilapangan. Tabel 1 merupakan daftar 30 APU 131-9 yang mengalami perawatan pada tahun 2017.

Tabel 1. Daftar Proyek Perawatan APU Tahun 2017

\begin{tabular}{cllcc}
\hline No & APU Serial Number (SN) & Pelanggan & APU Type & Contractual TAT \\
\hline $\mathbf{1}$ & P-6108 & Citilink & $131-9 \mathrm{~A}$ & 45 Days \\
$\mathbf{2}$ & P-3119 & Citilink & $131-9 \mathrm{~A}$ & 45 Days \\
$\mathbf{3}$ & P-5626 & Citilink & $131-9 \mathrm{~A}$ & 45 Days \\
$\mathbf{4}$ & P-5938 & Citilink & $131-9 \mathrm{~A}$ & 45 Days \\
$\mathbf{5}$ & P-5229 & Fortran & $131-9 \mathrm{~B}$ & 45 Days \\
$\mathbf{6}$ & P-5667 & GA & $131-9 \mathrm{~B}$ & 45 Days \\
$\mathbf{7}$ & P-6284 & GA & $131-9 \mathrm{~B}$ & 45 Days \\
$\mathbf{8}$ & P-6423 & GA & $131-9 \mathrm{~B}$ & 45 Days \\
$\mathbf{9}$ & P-8236 & GA & $131-9 \mathrm{~B}$ & 45 Days \\
$\mathbf{1 0}$ & P-8384 & GA & $131-9 \mathrm{~B}$ & 45 Days \\
$\mathbf{1 1}$ & P-8540 & GA & $131-9 \mathrm{~B}$ & 45 Days \\
$\mathbf{1 2}$ & P-8573 & GA & $131-9 \mathrm{~B}$ & 45 Days \\
$\mathbf{1 3}$ & P-8634 & GA & $131-9 B$ & 45 Days \\
$\mathbf{1 4}$ & P-8647 & GA & $131-9 B$ & 45 Days \\
$\mathbf{1 5}$ & P-8814 & GA & $131-9 B$ & 45 Days \\
$\mathbf{1 6}$ & P-9785 & GA & $131-9 B$ & 45 Days \\
$\mathbf{1 7}$ & P-9839 & GA & $131-9 B$ & 45 Days \\
$\mathbf{1 8}$ & P-9872 & GA & $131-9 B$ & 45 Days \\
\hline
\end{tabular}




\begin{tabular}{cllcc}
\hline No & APU Serial Number $($ SN $)$ & Pelanggan & APU Type & Contractual TAT \\
\hline $\mathbf{1 9}$ & P-9971 & GA & $131-9 B$ & 45 Days \\
$\mathbf{2 0}$ & P-9993 & GA & $131-9 B$ & 45 Days \\
$\mathbf{2 1}$ & P-10049 & GA & $131-9 B$ & 45 Days \\
$\mathbf{2 2}$ & P-10077 & GA & $131-9 B$ & 45 Days \\
$\mathbf{2 3}$ & P-10156 & GA & $131-9 B$ & 45 Days \\
$\mathbf{2 4}$ & P-5229 & GA & $131-9 B$ & 45 Days \\
$\mathbf{2 5}$ & P-5106 & Sriwijaya & $131-9 B$ & 45 Days \\
$\mathbf{2 6}$ & P-5489 & Sriwijaya & $131-9 B$ & 45 Days \\
$\mathbf{2 7}$ & P-5803 & Sriwijaya & $131-9 B$ & 45 Days \\
$\mathbf{2 8}$ & P-6239 & Sriwijaya & $131-9 B$ & 45 Days \\
$\mathbf{2 9}$ & P-7142 & Sriwijaya & $131-9 B$ & 45 Days \\
$\mathbf{3 0}$ & P-9932 & GA & $131-9 B$ & 45 Days \\
\hline
\end{tabular}

\subsection{Pengolahan Data}

Dalam pengolahan data ini berisi perhitungan hasil dari pengolahan data yang diperlukan dalam penelitian.

1. TAT standar.

Data TAT standar diambil dari hasil pengecekan pada laporan mingguan untuk kemudian dianalisis menggunakan gate sheet pada setiap proyek APU yang mengalami perawatan. Gambar 2 merupakan gate sheet menggunakan metode Gantt chart pada perbaikan APU ASN P-10077 yang telah distandarkan selama 45 hari kalender.

2. TAT Delay.

Gambar 3 adalah gate sheet dengan Gantt chart pada perawatan APU ASN P-7142, aktual oleh perusahaan selama 68 hari. Total keseluruhan terdapat 30 APU yang mengalami perawatan selama tahun 2017. Dalam check sheet tersebut menunjukkan Gating system proses maintenance APU, yang melalui 9 gate, yang dimulai dengan Gate 0 yaitu proses APU induction dan diakhiri dengan Gate 9 yaitu proses APU serviceable. Selanjutnya dilakukan pengambilan data untuk 30 APU yang mengalami perawatan selama tahun 2017.

3. Check sheet total TAT delay tiap gate.

Tabel 4 merupakan data delay APU berjumlah 15 APU Serial Number (ASN), dari total 30 APU yang mengalami perawatan selama tahun 2017. Dari data tersebut, APU tepat waktu (on time) berjumlah 15 ASN dan APU delay berjumlah 15 ASN.

4. Pareto TAT delay tahun 2017 dari check sheet perlu diketahui persentase delay dari setiap gate. Maka dari itu, perlu dilakukan analisis menggunakan Pareto diagram, seperti ditunjukkan pada Gambar 4. Berdasarkan Gambar 4, diketahui bahwa gate yang paling banyak mengalami delay mencapai lebih dari $80 \%$ berjumlah 4 gate. Gate 5 merupakan gate dengan delay paling lama, yaitu mencapai 47 hari, lalu diikuti dengan gate 3, selama 25 hari, lalu gate 8 dengan penundaan selama 24 hari, dan terakhir gate 7, dengan delay selama 17 hari. Maka total delay pada perbaikan APU pada tahun 2017 yaitu mencapai 136 hari.

5. Analisis Metode 5 Why's Analysis.

Dari data penelitian yang ada dapat dilakukan analisis Gate yang paling lama mengalami delay yaitu Gate 5, Gate 3, Gate 8 dan Gate 7, menggunakan metode 5 Whys Analysis. Analisis ini digunakan untuk mencari akar permasalahan dengan menanyakan kepada narasumber di bidang terkait dengan pertanyaan "mengapa" sebanyak 5 kali sampai ditemukan akar permasalahan yang ada. Analisis ini dilakukan terhadap permasalahan keterlambatan pengembalian APU kepada pelanggan. Tabel 5 menggambarkan analisis dengan metode 5 Whys. 


\section{APU MRO Progress Report}

\begin{tabular}{l|l|} 
& \\
Engine Serial Number: & P-10077 \\
Customer: & Garuda Indonesia \\
Project Number: & A-000202 \\
Contractual TAT: & 45
\end{tabular}

TAT Bar $\begin{aligned} \text { Material Coordinator: } & \text { Andrian } \\ \text { Production Control: } & \text { Andrian IJak }\end{aligned}$

\section{Todays Date}

Team Lead: Andrian

Gineering: Sindu Erbian

lity: Sudarno

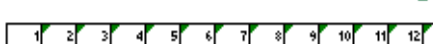

Present Gate "4" Materials Readiness

Start of Gate"

Gate "5" Delat

End Validation for Gate "5" Material Readiness

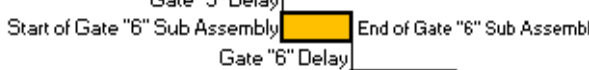

Start of Gate "7" Final Assembly, Gate "7"Delay Gate "7" Final Assembly

Start of Gate "8" Test
Gate "8" Delay Gate "8" Test

Gate "8" Delay $\square$ Gate "9" Serviceable \& Ship

Gate "9" Delay
Customer Delay

| Ist lnyoice and Exit Meeting

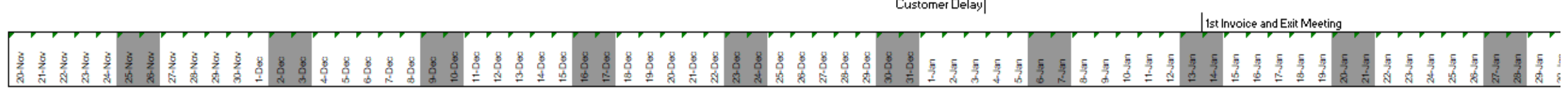

Gambar 2. Gate Sheet Maintenance APU Standar

6 | J I E M S 
Tabel 2. Keterangan Gating System Standar

\begin{tabular}{|c|c|c|}
\hline Gate & Aktivitas & Uraian Pekerjaan \\
\hline $\mathbf{0}$ & Pengenalan APU & $\begin{array}{l}\text { Pengumpulan data-data sebelum APU dibongkar dan sudah di } \\
\text { borescope }\end{array}$ \\
\hline 1 & Pembongkaran APU & $\begin{array}{l}\text { APU dibongkar selama } 3 \text { hari, didahulukan untuk bagian } O V \text { dan fast } \\
\text { track }\end{array}$ \\
\hline 2 & Pengiriman Part ke vendor & Part yang fast track langsung dikirim ke vendor \\
\hline 3 & Pembersihan dan Inspeksi & $\begin{array}{l}\text { Setelah APU dibongkar langsung masuk ke proses cleaning lalu NDT } \\
\text { dan kemudian inspeksi }\end{array}$ \\
\hline 4 & $\begin{array}{l}\text { Penerimaan Logistic (bahan } \\
\text { baku) }\end{array}$ & Proses pengadaan barang yang dibeli maupun yang di repair \\
\hline 5 & $\begin{array}{l}\text { Penggantian Logistic (bahan } \\
\text { baku) }\end{array}$ & $\begin{array}{l}\text { Proses menyiapkan barang dan dikelompokkan untuk persiapan } \\
\text { perakitan }\end{array}$ \\
\hline 6 & Memulai sub perakitan & Memulai proses perakitan sub-sub part \\
\hline 7 & Memuali perakitan Total & $\begin{array}{l}\text { Memulai penyatuan tiap-tiap bagian part agar menjadi satu bentuk } \\
\text { yang utuh }\end{array}$ \\
\hline 8 & Test APU & $\begin{array}{l}\text { APU di test cell dan di borescope untuk memastikan APU benar-benar } \\
\text { siap. }\end{array}$ \\
\hline 9 & Dokumentasi APU & $\begin{array}{l}\text { Penyiapan dokumen-dokumen penting agar APU layak dan resmi } \\
\text { digunakan. }\end{array}$ \\
\hline
\end{tabular}




\section{APU MRO Progress Report}

\section{1-Aug-18 Todays Date}

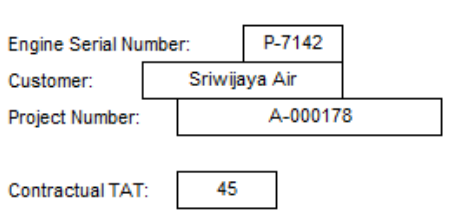

\begin{tabular}{rll} 
& \multicolumn{2}{c}{ Engine Owner Team } \\
Team Lead: & Ujang Saeful \\
Engineering: & Yuli / Sindu \\
Quality: & Edison \\
Praterial Coordinator: & Ujang Saeful \\
Production Control: & Ujang Saeful
\end{tabular}
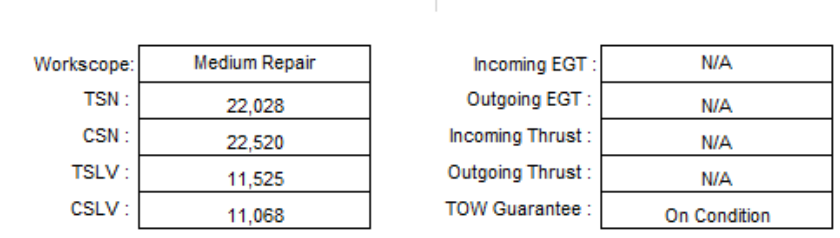

\begin{tabular}{|r|c|}
\hline Engine received : & 10-Jun-17 \\
\hline Engine inducted Gate 0: & 19-Jul-17 \\
\hline TAT "45 Day" Mark: & 2-Sep-17 \\
\hline TAT Actual : & 68 \\
\hline Committed Date : & $27-$ Sep-17 \\
\hline Days in Shop : & 107 \\
\hline Metrics : & 68 \\
\hline
\end{tabular}

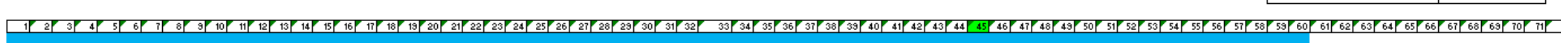

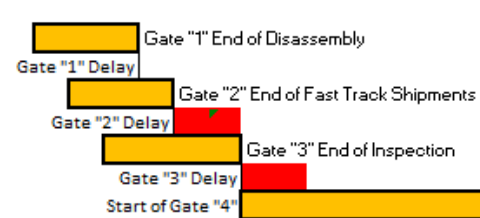

Present Gate "4" Materiat

Start of Gate "5"

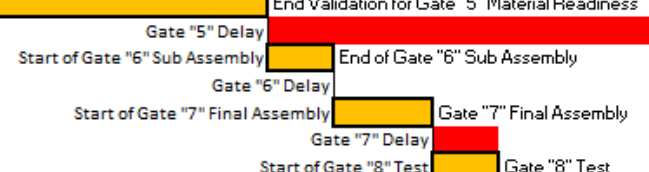

Start of Gate "8" Test $\square$ Gate "8" Test

Gate "8" Delay $\square$ Gate"g" Serviceates 8 Ship

Gate "g" Delay

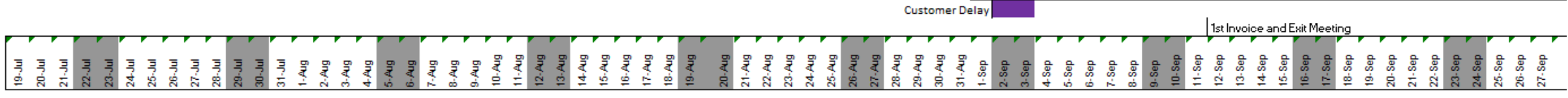

Gambar 3. Gate Sheet Maintenance APU Delay 
Tabel 3. Keterangan Gating System Aktual dan Akar Masalah

\begin{tabular}{|c|c|c|c|c|c|}
\hline Gate & Aktivitas & Rencana & Aktual & Status & Akar Masalah Keterlambatan \\
\hline $\mathbf{0}$ & Pengenalan APU & 19-Jul-17 & 19-Jul-17 & $\mathrm{OK}$ & - \\
\hline 1 & $\begin{array}{l}\text { Pembongkaran } \\
\text { APU }\end{array}$ & 21-Jul-17 & 21-Jul-17 & OK & - \\
\hline 2 & $\begin{array}{l}\text { Pengiriman Part } \\
\text { ke vendor }\end{array}$ & 22-Jul-17 & 24-May-17 & Terlambat & $\begin{array}{l}\text { Poses } O V \text { Lube module terlambat } \\
\text { selama dua hari karena masalah } R O \\
\text { oleh Unit TDC }\end{array}$ \\
\hline 3 & $\begin{array}{l}\text { Pembersihan dan } \\
\text { Inspeksi }\end{array}$ & 24-Jul-17 & 26-Jul-17 & Terlambat & $\begin{array}{l}2 \text { hari tertunda karena kekurangan } \\
\text { pekerja. }\end{array}$ \\
\hline 4 & $\begin{array}{l}\text { Penerimaan } \\
\text { Logistic (bahan } \\
\text { baku) }\end{array}$ & 12-Aug-17 & 12-Aug-17 & OK & - \\
\hline 5 & $\begin{array}{l}\text { Penggantian } \\
\text { Logistic (bahan } \\
\text { baku) }\end{array}$ & 25-Aug-17 & 12-Sep-17 & Terlambat & $\begin{array}{l}19 \text { hari tertunda karena menunggu } \\
\text { material dari pihak vendor luar. }\end{array}$ \\
\hline 6 & $\begin{array}{l}\text { Memulai sub } \\
\text { perakitan }\end{array}$ & 25-Aug-17 & 26-Aug-17 & OK & - \\
\hline 7 & $\begin{array}{l}\text { Memuali } \\
\text { perakitan Total }\end{array}$ & 29-Aug-17 & 31-Aug-17 & Terlambat & $\begin{array}{l}\text { Menunggu Lube Module dari } \\
\text { pemasok pelanggan }\end{array}$ \\
\hline 8 & Test APU & 31-Aug-17 & 31-Aug-17 & OK & - \\
\hline 9 & $\begin{array}{l}\text { Dokumentasi } \\
\text { APU }\end{array}$ & 2-Sep-17 & 27-Sep-17 & Terlambat & TAT tertunda selama 23 hari. \\
\hline
\end{tabular}

Tabel.4. Check Sheet Data Delay TAT APU Tahun 2017

\begin{tabular}{|c|c|c|c|c|c|c|c|c|c|c|c|c|c|}
\hline \multirow{2}{*}{ No } & \multirow{2}{*}{ SN } & \multicolumn{10}{|c|}{ TAT Delay Gates } & \multirow{2}{*}{ Total Days } & \multirow{2}{*}{ Note } \\
\hline & & $\mathbf{0}$ & 1 & 2 & 3 & 4 & 5 & 6 & 7 & 8 & 9 & & \\
\hline 1 & P-6108 & & & & & & & & & & & 0 & On Time \\
\hline 2 & P-3119 & & & & & & 23 & & & & & 23 & Delay \\
\hline 3 & P-5626 & & & & & & 4 & & & & & 4 & Delay \\
\hline 4 & P-5938 & & & & 5 & & & & & & & 5 & Delay \\
\hline 5 & P-5229 & & & & & & & & & & & 0 & On Time \\
\hline 6 & P-5667 & & & & & & & & & & & 0 & On Time \\
\hline 7 & P-6284 & & & & & 3 & & & & & & 3 & Delay \\
\hline 8 & P-6423 & & & & 2 & & & & & & & 2 & Delay \\
\hline 9 & P-8236 & 2 & & & 2 & & & & & & & 4 & Delay \\
\hline 10 & P-8384 & & & & & & & & & & & 0 & On Time \\
\hline 11 & P-8540 & & & & 4 & & & 7 & 4 & & & 15 & Delay \\
\hline 12 & P-8573 & & & & & & & & & & & 0 & On Time \\
\hline 13 & P-8634 & & & & & & & & & & & 0 & On Time \\
\hline 14 & P-8647 & & & & & & & & & & & 0 & On Time \\
\hline 15 & P-8814 & 2 & & & 2 & & & & & & & 4 & Delay \\
\hline 16 & P-9785 & & & & & & & & & & & 0 & On Time \\
\hline 17 & P-9839 & & & & & & & & & & & 0 & On Time \\
\hline 18 & P-9872 & & & & & & & & & & & 0 & On Time \\
\hline 19 & P-9971 & & & & & & & & & & & 0 & On Time \\
\hline 20 & P-9993 & & & & & & & & & & & 0 & On Time \\
\hline 21 & P-10049 & & & & 1 & & & & & & & 1 & Delay \\
\hline 22 & P-10077 & & & & & & & & & & & 0 & On Time \\
\hline 23 & P-10156 & & & & & & & & & & & 0 & On Time \\
\hline 24 & P-5229 & & & & & & & & & & & 0 & On Time \\
\hline 25 & P-5106 & & & & 2 & & & & & & & 2 & Delay \\
\hline 26 & P-5489 & & & & 5 & & & & & & & 5 & Delay \\
\hline 27 & P-5803 & & & & & 1 & 1 & & & 2 & & 4 & Delay \\
\hline 28 & P-6239 & & & & & & & & 11 & 7 & & 18 & Delay \\
\hline 29 & P-7142 & & & & 2 & & 19 & & 2 & & & 23 & Delay \\
\hline 30 & P-9932 & & & & & 8 & & & & 15 & & 23 & Delay \\
\hline \multicolumn{2}{|c|}{ Total Days } & 4 & 0 & 0 & 25 & 12 & 47 & 7 & 17 & 24 & 0 & 136 & \\
\hline
\end{tabular}




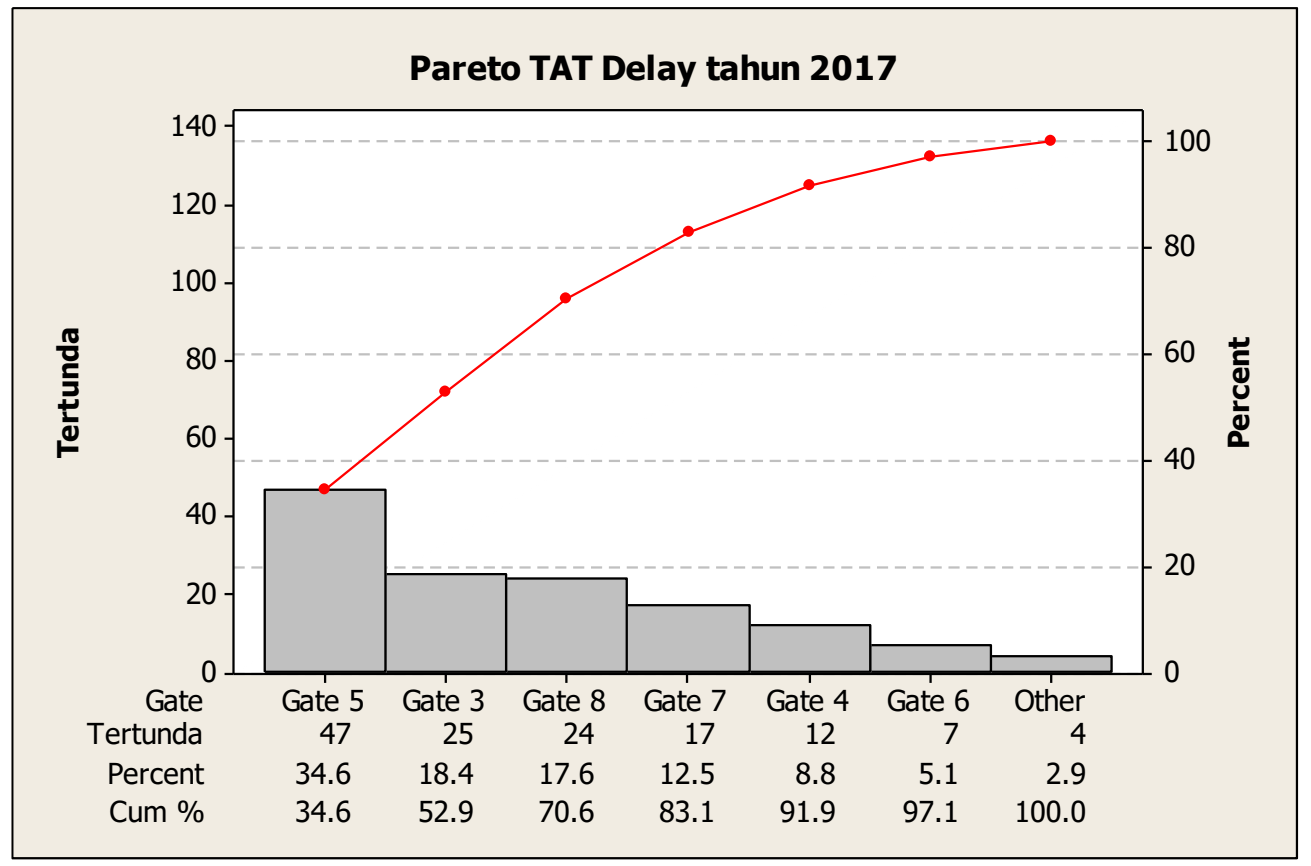

Gambar 4. Pareto TAT Delay Tahun 2017

Tabel 5. Analisis 5 Whys

\begin{tabular}{|c|c|c|c|c|c|}
\hline Gate & Why 1 & Why 2 & Why 3 & Why 4 & Why 5 \\
\hline 5 & $\begin{array}{l}\text { Komponen } \\
\text { utama belum } \\
\text { siap dirakit }\end{array}$ & $\begin{array}{l}\text { Pengiriman } \\
\text { komponen ke } \\
\text { outsource vendor } \\
\text { untuk perbaikan }\end{array}$ & $\begin{array}{l}\text { Kapabilitas } \\
\text { perbaikan } \\
\text { terbatas }\end{array}$ & $\begin{array}{l}\text { Tools, equipment } \\
\text { dan panduan } \\
\text { manual belum } \\
\text { siap }\end{array}$ & $\begin{array}{l}\text { permohonan izin } \\
\text { perbaikan komponen } \\
\text { di internal }\end{array}$ \\
\hline 3 & $\begin{array}{l}\text { Lamanya proses } \\
\text { inspeksi }\end{array}$ & $\begin{array}{l}\text { Kekurangan tenaga } \\
\text { kerja }\end{array}$ & $\begin{array}{l}\text { Belum } \\
\text { siapnya } \\
\text { tenaga kerja }\end{array}$ & $\begin{array}{l}\text { pengalaman dan } \\
\text { mentoring } \\
\text { personil baru }\end{array}$ & $\begin{array}{l}\text { Training dan OJT } \\
\text { personel baru }\end{array}$ \\
\hline 8 & $\begin{array}{l}\text { Troubleshoot } \\
\text { pada test } \\
\text { kelayakan APU }\end{array}$ & $\begin{array}{l}\text { Rubbing damage } \\
\text { pada comprossor }\end{array}$ & $\begin{array}{l}\text { Tidak presisi } \\
\text { saat asembly }\end{array}$ & $\begin{array}{l}\text { Tenaga kerja } \\
\text { tidak pengalaman }\end{array}$ & $\begin{array}{l}\text { Belum ada Coaching } \\
\text { dan mentoring pada } \\
\text { Assy komponen } \\
\text { untama }\end{array}$ \\
\hline 7 & $\begin{array}{l}\text { Antrian pada line } \\
\text { assembly }\end{array}$ & $\begin{array}{l}\text { kapasistas line } \\
\text { assembly terbatas }\end{array}$ & $\begin{array}{l}\text { Tools dan } \\
\text { equpment } \\
\text { terbatas }\end{array}$ & $\begin{array}{l}\text { belum dibeli pada } \\
\text { vendor }\end{array}$ & $\begin{array}{l}\text { Investasi dan } \\
\text { rencana penambahan } \\
\text { kapasitas assembly } \\
\text { belum ada }\end{array}$ \\
\hline
\end{tabular}

\subsection{Analisis dan Pembahasan}

Setelah melakukan penelitian terhadap proyek APU 131-9 tahun 2017, maka selanjutnya adalah merangkum atau membuat penyajian dari hasil analisis dimana terdapat 4 masalah pada gate, yaitu gate 3 , gate 5 , gate 7 , dan gate 8. Untuk menentukan perbaikan yang tepat maka dilakukan analisa dari proses gate yang terlama yaitu dimulai dari gate 5 dimana proses tertunda sampai dengan 45 hari, gate 3 proses tertunda selama 25 hari, gate 8 proses tertunda selama 24 hari, dan gate 7 proses tertunda selama 17 hari. hasil dari analisis dan pembahasan serta usulan perbaikan dapat dilihat pada Tabel 6.

Dari Tabel 6 dapat dilihat bahwa tahapan yang harus dilakukan untuk usulan perbaikan perbaikan adalah:

1. Penambahan kapabilitas dan hak perbaikan komponen utama kepada honeywell.

2. Penambahan tenaga kerja yang terampil.

3. Pembuatan silabus pelatihan dan melakukan mentoring kepada personel yang belum berpengalaman.

4. Investasi penambahan lini perakitan dan peralatan yang dibutuhkan untuk merakit APU. 
Tabel 6 Hasil Analisis dan Pembahasan

No Hasil Analisis dan Pembahasan

1 Pada proses di gate 5 terjadi delay paling lama yaitu mencapai 47 hari, dapat dilihat pada 5 whys analysis, bahwa masih terbatasnya kapabilitas perbaikan APU, dikarenakan belum mendapatkan izin dari vendor APU, yaitu Honeywell yang merupakan Produsen dari APU 131-9.

2 Pada proses gate 3, delay selama 25 hari, dapat diketahui bahwa lamanya proses detailed inspection, dikarenakan kekurangan tenaga kerja dan personil baru yang belum siap kerja serta belum berpengalaman, seorang teknisi, perlu sekitar 5 tahun, untuk siap di lepas bekerja tanpa diawasi atau disupervisi.

3 Delay di gate 8, selama 24 hari, karena terjadinya troubleshoot pada pengujian kelayakan APU di test cell, karena ada masalah teknis yang disebabkan kesalahan dan kurang presisi pada saat assembly APU, dikarenakan personil baru dan belum berpengalaman, serta kurang nya coaching dan mentoring.

4 Gate 7, delay selama 17 hari, karena terjadinya antrian pada line assembly pada saat APU siap di pasang pada setiap komponen nya, ternyata belum siap line dan equipment yang terbatas, sehingga menyebabkan antrian pada APU yang siap untuk di pasang.
Penambahan kapabilitas dan hak perbaikan komponen utama atau fast track kepada Honeywell, sebagai produsen dari APU 131-9 untuk dikerjakan di dalam workshop PT. GAA, sehingga dapat mempersingkat waktu tunggu pada saat persiapan pemasangan komponen dan hemat biaya pengiriman.

Penambahan tenaga kerja yang terampil dan siap kerja serta di bekali dengan kemampuan administrasi system SAP dan Swift, Pengukuran dan izin otorisasi dari Unit Quality untuk klaim pekerjaan.

Dibuat sylabus training dan lakukan mentoring oleh personil yang berpengalaman pada assembly APU, terhadap mentee yang belum berpengalaman dalam pekerjaan yang menggunakan pengukuran tertentu, serta melakukan kontrol pada pekerjaan yang di butuhkan ketelitian dan pengukuran yang presisi.

Penambahan line assembly, tools dan equipment yang di butuhkan untuk merakit APU, serta perencanaan yang lebih baik terhadap setiap proyek APU yang di kerjakan.

\section{SIMPULAN}

Berdasarkan hasil analisis penelitian di PT. GAA, dapat diambil kesimpulan antara lain adalah Proses perbaikan APU 131-9 yang telah distandarkan yaitu 45 Hari, Pada proses perbaikan APU harus melewati 10 gate yaitu Gate 0-9. pada penelitian ini, proses yang mengalami keterlambatan terdapat 4 gate yaitu pada proses gate 5 dimana Proses menyiapkan komponen utama untuk persiapan perakitan, gate 3 dimana Proses Cleaning, NDT dan DVI (Detailed Visual Inspection), Gate 8 Proses Pengujian kelayakan APU di Test Cell dan Gate 7 saat proses perakitan komponen APU lainnya. Berdasarkan analisis dengan menggunakan metode Gantt chart dan 5 whys analysis didapat penyebab masalah TAT pengembalian yang melewati batas 45 hari, ditemukan 4 Penyebab yaitu: Masih terbatasnya kapabilitas perbaikan APU, di karenakan belum mendapatkan izin dari produsen APU 131-9, yaitu Honeywell, khusus nya untuk perbaikan komponen di internal workshop, Lama nya proses detailed inspection dikarenakan kekurangan personil yang menyebabkan pekerjaan mengalami keterlambatan, Masalah teknis yang terjadi pada saat pengujian APU setelah proses perakitan, disebabkan kesalahan dan kurang presisi pada saat pemasangan komponen utama, khususnya yang bergerak secara berputar atau rotary, dan Terjadinya antrian pada saat pemasangan APU yang disebabkan kekurangan line pemasangan serta peralatan dan perlengkapan yang terbatas.

Saran untuk masalah TAT ini adalah perlu ditambahnya kapabilitas dan kuantitas perbaikan APU 131-9, penambahan tenaga kerja yang terlatih sesuai dengan bidang kerja masingmasing, baik secara teknis maupun administrasi. Terakhir adalah kontrol terhadap proses perbaikan APU pada 10 Gating System.

\section{DAFTAR PUSTAKA}

Arikunto, S. (2006) Metode Penelitian Kualitatif. Jakarta: Bumi Aksara.

Baker, K. R. (1974) Introduction to Sequencing and Scheduling. New York: John Wiley and Sons.

Biegel, J. E. (1992) Production Control. New York: Prentice Hall. 
Conway, R. W., Maxwell, W. L. dan Miller, L. W. (2003) Theory of Scheduling. New York: Dover Publications.

International Air Transport Association (2014) Component Maintenance - Best Practices: An Airline Perspective. Athens. Tersedia pada: https://www.iata.org/whatwedo/workgro ups/Documents/MCC-2014ATH/D2/0830-0910-comp-mtce-costVirginAustralia.pdf.

International Air Transport Association (2015) Reducing Component Repair Costs and Turn Around Times. Miami. Tersedia pada: https://www.iata.org/whatwedo/workgro ups/Documents/MCC-2015-

MIA/D1_1420-1455_-

_Reducing_Compnt_Repair_Cost_n_TA Ts_-_Gavin_Simmons.pdf.

Madura, J. (2007) Introduction to Business. 4 ed. Mason: Thomson South-Western.

Rajarajan, S. S. (2014) Aircraft Parts Planning Taming the Chaos. Tersedia pada: https://www.ramco.com/downloads/aircr aft_parts.pdf.

Sugiyono (2011) Metode Penelitian Kuantitatif Kualitatif dan R\&D. Bandung: Alfabeta. 